\title{
PELAKSANAAN KERJA PENYELENGGARAAN RUMAH KEDAI LAMA DALAM ZON WARISAN DI KOTA BHARU KELANTAN, MALAYSIA
}

\author{
FARRAH ATIKAH SAARI \\ MOHAMMAD RUSDI MOHD NASIR** \\ WAN SAIFUL NIZAM WAN MOHAMAD*** \\ NASIRIN BIN ABDILLAH ${ }^{* * * *}$ \\ SITI NUR ANIS BINTI MUHAMMAD APANDI***** \\ atikah.s@umk.edu.my*,rusdi.mn@umk.edu.my**, saifulnizam@umk.edu.my***, \\ nasirin@umk.edu.my****,nuranis.m@umk.edu.my*****
}

\begin{abstract}
Abstrak
Bangunan rumah kedai lama merupakan aset yang memaparkan sejarah identiti pembentukan sesebuah negeri dan ia seharusnya dikekalkan untuk generasi baru. Namun kini, kebanyakan rumah kedai lama sedang diancam kepupusan kerana tiadanya proses penyelenggaraan yang baik. Bagi mengekalkan kelangsungan hayat bangunan rumah kedai lama, penyelenggaraan terhadap keadaan dan fungsi bangunan perlu dilaksanakan dengan penyediaan sistem pengurusan penyelenggaraan yang sistematik. Sehubungan itu, objektif kajian ini adalah untuk mengenalpasti jenis-jenis penyelenggaraan yang telah dilaksanakan ke atas bangunan rumah kedai lama. Selain itu, kesan dan cadangan bagi kerja-kerja penyelenggaraan yang dilaksanakan juga turut dikaji. Kajian ini merupakan kajian kualitatif yang menggunakan kaedah pemerhatian dan temubual. Berdasarkan dapatan kajian, terdapat proses penyelenggaraan yang dilaksanakan terhadap struktur dinding, siling, lantai, cat dan fasad. Kerja-kerja penyelenggaraan yang dilaksanakan juga memberi impak yang positif terhadap nilai warisan. Saranan untuk menetapkan polisi khusus bagi penyelenggaraan bangunan warisan serta penglibatan semua pihak yang berkepentingan dalam usaha untuk melestarikan bangunan rumah kedai lama turut dikemukakan. Sebagai kesimpulan, hasil kajian ini telah menggariskan beberapa cadangan yang boleh dijadikan panduan oleh pihak berkuasa tempatan dalam melaksanakan kerja-kerja penyelenggaraan mengikut kaedah pemeliharaan yang lebih baik agar nilai warisan terus terjaga.
\end{abstract}

Kata Kunci: Bangunan, Pengurusan, Penyelenggaraan, Rumah Kedai, Sistem

* Pensyarah di Fakulti Teknologi Kreatif dan Warisan, Universiti Malaysia Kelantan, Malaysia

** Profesor Madya di Fakulti Senibina dan Ekistik, Universiti Malaysia Kelantan, Malaysia

*** Pensyarah Kanan di Fakulti Senibina dan Ekistik, Universiti Malaysia Kelantan, Malaysia

**** Pensyarah di Fakulti Teknologi Kreatif dan Warisan, Universiti Malaysia Kelantan, Malaysia

***** Pensyarah di Fakulti Teknologi Kreatif dan Warisan, Universiti Malaysia Kelantan, Malaysia 


\title{
THE IMPLEMENTATION OF MAINTENANCE WORKS ON OLD SHOP HOUSES IN THE HERITAGE ZONE AT KOTA BHARU KELANTAN MALAYSIA
}

\author{
FARRAH ATIKAH SAARI* \\ MOHAMMAD RUSDI MOHD NASIR** \\ WAN SAIFUL NIZAM WAN MOHAMAD*** \\ NASIRIN BIN ABDILLAH**** \\ SITI NUR ANIS BINTI MUHAMMAD APANDI***** \\ atikah.s@umk.edu.my*, rusdi.mn@umk.edu.my**, saifulnizam@umk.edu.my**, \\ nasirin@umk.edu.my ${ }^{* * * *}$,nuranis.m@umk.edu.my*****
}

\begin{abstract}
Old shop house building is an asset that displays the history of the identity of the formation of a state and it should be preserved for the new generation. But now, most old shop houses are threatened with extinction due to lack of good maintenance process. To maintain the longevity of old shop house building, maintenance of the condition and function of the building must be implemented with the provision of a systematic maintenance management system. Accordingly, the objective of this study is to find out the types of maintenance that have been implemented on the old shop house building. In addition, the effects of and recommendations for maintenance work carried out are also considered. This qualitative study uses observation and interview methods. Based on the findings, the study shows that there is a maintenance process that has been carried out on the structure of walls, ceilings, floors, paints and facades. The undertaken maintenance works also indicate a positive impact on heritage value. This study also proposes that a specific maintenance policy be adopted for the heritage buildings and effective involvement of all parties be encouraged in the effort of preserving the old shop house building. In conclusion, this study has provided some recommendations for local authorities to consider in undertaking the maintenance works so that proper conservation methods can be practiced and heritage values can be maintained.
\end{abstract}

Keywords: Building, Management, Maintenance, Shop House, System

* Lecturer at Faculty of Creative Technology and Heritage, Universiti Malaysia Kelantan, Malaysia

** Associate Professor at Faculty of Architecture and Ekistics, Universiti Malaysia Kelantan, Malaysia

*** Senior Lecturer at Faculty of Architecture and Ekistics, Universiti Malaysia Kelantan, Malaysia

**** Lecturer at Faculty of Creative Technology and Heritage, Universiti Malaysia Kelantan, Malaysia

***** Lecturer at Faculty of Creative Technology and Heritage, Universiti Malaysia Kelantan, Malaysia 


\subsection{Pengenalan}

Bangunan lama terutamanya rumah kedai bertindak sebagai komponen penting yang menyumbang dalam membentuk identiti sesebuah bandar. Paling penting, rumah kedai lama ini mempunyai banyak ciri sejarah yang membolehkan Pihak Berkuasa Tempatan (PBT) dan komuniti menghargai warisan untuk melindungi dan memelihara bangunan terutama dari tekanan pembangunan. Beberapa kajian yang dijalankan di rumah kedai di Malaysia menyimpulkan bahawa suasana rumah kedai lama di bandar pada zaman sekarang hanya kekal di dalam ingatan generasi lama kerana faktor pembangunan moden yang agresif, (Wan Ismail, W.H., 2012).

Selain daripada arus pembangunan moden yang agresif, bangunan rumah kedai lama juga sering kali dikaitkan dengan rumah kedai lama yang tidak menjalankan kerja-kerja pemuliharaan dan pemeliharaan dan dibiarkan rosak serta ditinggalkan begitu sahaja, Bakhir, N. M., dan Zainal, N. (Eds.). (2015). Bagi mengekalkan kelangsungan hayat bangunan rumah kedai lama, penyelenggaraan terhadap keadaan dan fungsi bangunan perlu dilaksanakan dengan penyediaan sistem pengurusan penyelenggaraan yang sistematik. Sehubungan itu, bagi melaksanakan sistem pengurusan penyelenggaraan yang efektif, adalah penting untuk mengetahui jenis-jenis penyelenggaraan yang telah dilaksanakan ke atas rumah kedai lama bagi memastikan kerja-kerja yang dilaksanakan bersesuaian dengan keadaan rumah kedai lama tersebut.

\subsection{Sorotan Kajian}

Setiap bangunan bersejarah mempunyai keunikannya yang tersendiri dan ia dapat dilihat dari rupa seni binanya, bahan binaan, tempat perletakannya dan corak budaya penempatannya (cultural landskap). Orbasli (2008) menyatakan tidak lengkap sesuatu yang dipanggil sebagai alam binaan tanpa bangunan warisan. Kerja-kerja penyelenggaraan yang dilakukan ke atas bangunan rumah kedai lama seperti Kedai Emas Masmaya (Rajah 1) dapat mengekalkan dan menghargai keunikan warisan yang terbina sejak zaman sebelum merdeka dan penting dari aspek pemuliharaan dan pemeliharaan kerana rumah kedai ini terletak di Zon Budaya Kota Bharu.

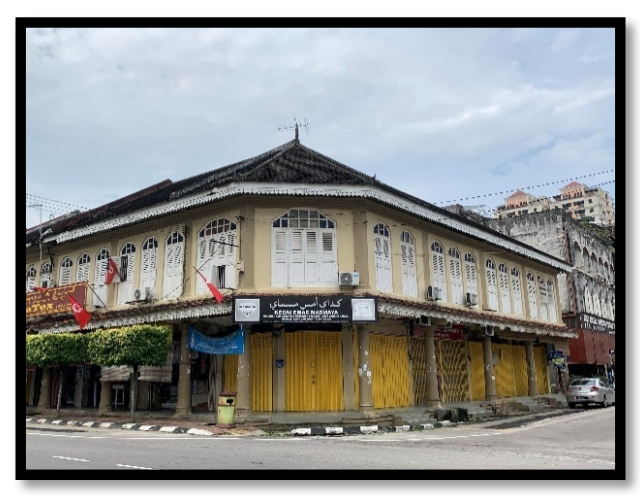

Rajah 1: Bangunan Kedai Emas Masmaya yang terletak dalam zon budaya di Kota Bharu Kelantan

(Sumber: Kajian Lapangan di Bandar Kota Bharu, 2020) 
Kesan proses penyelenggaraan yang dilaksanakan di bangunan kedai lama dapat menjaga nilai sejarah yang terdapat pada rumah kedai lama tersebut dan dapat dijadikan satu bukti kukuh tentang peristiwa yang terdapat di negeri Kelantan pada suatu ketika dahulu. Hal ini secara tidak langsung dapat dijadikan rujukan buat para sejarawan yang ingin mengkaji perkembangan pembangunan negeri Kelantan.

Seni bina menjadi cermin bagi identiti sesebuah pembinaan. Malahan seni bina menjadi aspek yang paling berharga dalam usaha mengekalkan sesebuah bangunan. Dalam konteks ini bangunan rumah kedai lama memenuhi salah satu ciri yang dinyatakan di dalam piagam Burra Charter iaitu pada Perkara 4.1, Jalan, P. P. K. P. P., dan Koridor, D. (2020) yang menyatakan bahawa pengertian tempat mempunyai definisi dan antaranya tapak, kawasan, tanah, landskap, bangunan, kumpulan bangunan dan termasuk komponen, kandungan, ruang dan kawasan sekitarnya. Pengkaji mendapati sekitar Zon Budaya di Kota Bharu kaya dengan pelbagai seni bina bangunan rumah kedai lama. Seni bina ni dipengaruhi oleh keadaan semasa bandar Kota Bharu pada masa lalu. Kepelbagaian seni bina ini bermula pada tahun 1940-an hingga ke tahun 1980 -an. Kesan proses penyelenggaraan yang dilakukan dapat menjaga seni bina yang ada daripada rosak dan dibiarkan bergitu sahaja. Kerja-kerja penyelenggaraan yang dilakukan oleh individu-individu yang berpengalaman dapat menjaga nilai seni bina yang terdapat pada rumah kedai lama. Hal ini kerana, mereka mengikut standad dan prosedur yang ditetapkan di dalam melakukan kerja-kerja penyelenggaraan.

Bagi negeri Kelantan, bangunan lama adalah satu identiti penting kepada masyarakat. Rumah kedai lama adalah bukti masyarakat Kelantan sudah berkembang dan maju suatu ketika dahulu, Jamal, D. H. D., dan Ramli, Z. (2021). Pengabaian tentang kepentingan dan sumbangan bangunan rumah kedai lama terhadap identiti bandar Kelantan akan menyebabkan hilangnya nilai warisan yang terdapat padanya. Kerja-kerja penyenggaraan yang dilakukan ke atas rumah kedai lama adalah satu tindakan yang baik kerana ia dapat memainkan peranan penting sebagai identiti di bandar warisan di Kelantan. Kerja-kerja penyelenggaraan yang dilakukan pada bangunan rumah kedai lama disekitar Kota Bharu bukan sahaja memenuhi keperluan sesetengah pemilik rumah kedai tetapi menimbulkan variasi visual yang indah dan menjadi imej kepada bandar di negeri Kelantan.

\subsection{Latar Belakang Kajian}

Zon budaya telah menjadi kajian kes kerana terletak di lokasi strategik di tengah-tengah bandar Kota Bharu yang memperlihatkan perkembangan pesat dan memainkan peranan penting dalam pembangunan bandar Kota Bharu itu sendiri. Ini selaras dengan apa yang dinyatakan oleh David, GS (1992) bahawa seni bina merupakan bukti sentuhan, percantuman dan perubahan budaya serta bukti perubahan dalam organisasi sosial, politik dan agama. Kajian juga mencadangkan penambahbaikan dalam proses penyelenggaraan yang boleh diguna pakai di dalam memelihara rumah kedai lama. 


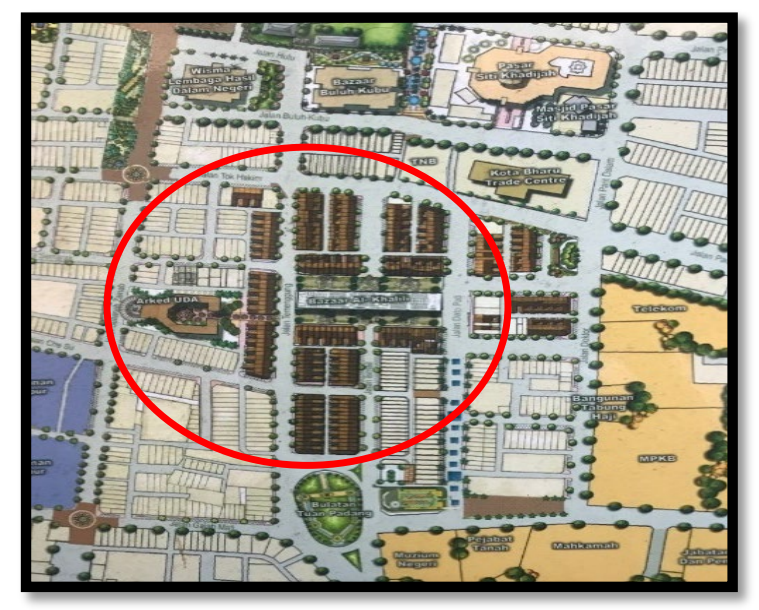

Rajah 2: Zon Budaya Kota Baharu

(Sumber: Majlis Perbandaran Kota Bharu, 2005)

Rajah 2 menunjukkan kawasan Zon Budaya Kota Bharu yang terdapat deretan blok rumah kedai lama. Bandar Kota Bharu terbahagi kepada dua zon penting iaitu Zon Warisan dan Zon Budaya. Zon Warisan yang merangkumi kawasan-kawasan yang mempunyai bangunan warisan sekitar Istana Jahar, Muzium Batu, Muzium Bank Krapu dan Istana Balai Besar. Manakala Zon Budaya meliputi kawasan bangunan rumah kedai lama sekitar Muzium Negeri Kelantan sehingga ke Pasar Siti Khadijah. Selain itu, bangunan bersejarah dikenali kerana sumbangannya terhadap nilai identiti kepada sesuatu tempat. Menurut Idid, S.Z.A (1996) menyatakan identiti adalah suatu kelainan yang terdapat pada citra atau imej sesuatu tempat sehingga membezakannya dengan tempat-tempat lain. Antara komponen yang memainkan peranan penting dalam menyumbang kepada pembentukan identiti sesuatu tempat ialah bangunan-bangunan lama. Oleh itu, pengkaji hanya mengambil empat bangunan rumah kedai iaitu Rumah Kedai Ubat Min Sin, No. 1233, Jalan Hilir Pasar, Rumah Kedai Klinik Foo, 3597, Jalan Ismail, Kedai Emas Masmaya, 349-D, Jalan Tengku Petra Semerah dan Rumah Kedai Win Suon Enterprise, 183 K-M, Jalan Ismail.

\subsection{Metodologi Kajian}

Tujuan kajian ini adalah mencadangkan proses penyelenggaraan terhadap bangunan rumah kedai lama yang dapat memberi kesan pada nilai warisan. Aspek ini melibatkan kajian jenis penyelenggaraan yang telah dilaksanakan ke atas bangunan rumah kedai lama yang dipilih. Disamping itu, kajian ini juga dapat membincangkan hubungan antara kerja penyelenggaraan yang dilaksanakan dengan kesan ke atas nilai warisan yang terdapat pada bangunan rumah kedai lama tersebut. Hubungan antara kerja penyelenggaraan yang dilaksanakan dengan faktor sejarah; seni bina dan budaya adalah saling berkaitan dan tidak boleh diabaikan semasa kerjakerja penyelenggaraan dilaksanakan. Kajian yang dilaksanakan oleh pengkaji merupakan kajian yang bersifat deskriptif. Kaedah penyelidikan yang digunakan ialah berbentuk tinjauan menggunakan pendekatan secara kualitatif menerusi pemerhatian dan temubual yang menggunakan alat rakaman seperti gambar, audio dan video. Empat bangunan rumah kedai yang dipilih telah menepati ciri-ciri elemen yang dikaji. Antara elemen yang diperhatikan oleh pengkaji ialah dinding, siling, lantai, cat/warna dan fasad. Sementara itu, empat orang responden 
juga telah dikenalpasti iaitu penghuni rumah kedai yang membantu pengkaji dalam menjawab persoalan berkaitan dengan penyelenggaraan yang dilaksanakan di bangunan rumah kedai lama. Menurut Courtenay, B., Merriam, S., dan Baumgartner, L. (2003), menyatakan bahawa penyelidikan kualitatif adalah bertujuan untuk kajian secara mendalam berkaitan dengan persoalan kajian. Kajian kualitatif merupakan kaedah pengumpulan maklumat, merekodkan data, menyelesaikan isu-isu lapangan serta menyimpan maklumat berkaitan dengan kajian yang dilakukan.

\subsection{Keputusan Dan Perbincangan}

\subsection{Penyelenggaraan yang telah dilaksanakan ke atas bangunan rumah kedai lama-}

Penyelenggaraan adalah kerja-kerja pembaikan dan penjagaan yang dijalankan ke atas struktur dan elemen-elemen yang terdapat pada bangunan warisan yang dikenalpasti serta mengalami kerosakan dan tidak berfungsi. Kerja-kerja penyelenggaraan biasanya dilakukan selepas pembinaan atau dalam suatu jangka masa yang lama dalam usaha untuk mengelakkan kemerosotan nilai senibina warisan. Rajah 3 hingga Rajah 6 menunjukkan empat bangunan rumah kedai yang telah dikenalpasti manakala Jadual 1 hingga Jadual 4 menunjukkan penyelenggaraan yang dilakukan terhadap rumah kedai tersebut.

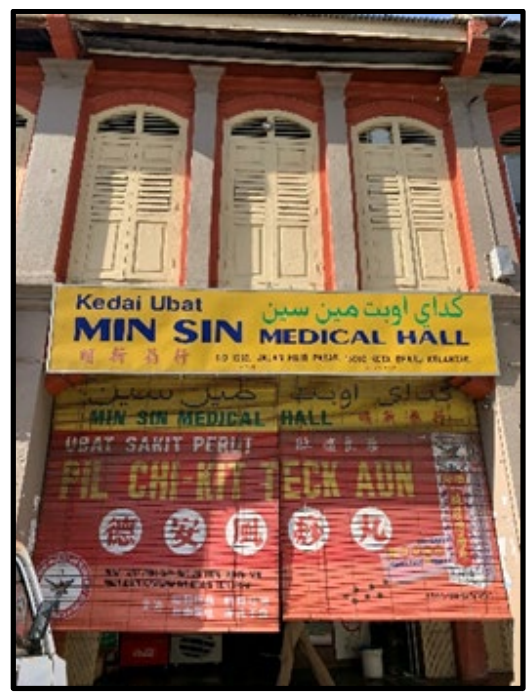

Rajah 3: Rumah Kedai Ubat Min Sin, No. 1233, Jalan Hilir Pasar, 15000 Kota Bharu, Kelantan

(Sumber: Kajian Lapangan di Bandar Kota Bharu, 2020) 
Jadual 1: Penyelenggaraan Terhadap Rumah Kedai Ubat Min Sin, No. 1233

(Sumber: Kajian Lapangan di Bandar Kota Bharu, 2020)

\begin{tabular}{|l|l|}
\hline Elemen & \multicolumn{1}{|c|}{ Huraian Bagi Setiap Elemen } \\
\hline Dinding & $\begin{array}{l}\text { Dinding kedai Ubat Min Sin tidak pernah diselenggara dan ia } \\
\text { dapat dilihat terdapat sedikit rekahan pada dinding luar kedai. } \\
\text { Rekahan tersebut tidak diselenggara dan dibiarkan bergitu } \\
\text { sahaja. }\end{array}$ \\
\hline Siling & $\begin{array}{l}\text { Penyelenggaraan pada bahagian siling hanya dilakukan sekali } \\
\text { sahaja. Selain daripada itu tidak lagi berlaku sebarang } \\
\text { penyelenggaraan. Hal ini dapat dilihat daripada reka bentuk } \\
\text { siling di rumah kedai beliau yang berbentuk segi empat sama. } \\
\text { Berbeza dengan bentuk siling yang ada pada masa kini. }\end{array}$ \\
\hline Lantai & $\begin{array}{l}\text { Pemilik Kedai Ubat Min Sin hanya melakukan penyelengaraan } \\
\text { terhadap lantai di bangunan rumah kedai milik beliau sekali } \\
\text { sahaja. laitu dengan mengemaskan lantai bangunan rumah } \\
\text { kedai dengan simen. Akan tetapi pengkaji mendapati terdapat } \\
\text { bahagian lantai yang sudah rosak dan berlaku rekahan. } \\
\text { Sekiranya dibiarkan ia akan mengundang bahaya kepada } \\
\text { pengguna. }\end{array}$ \\
\hline Cat/Warna & $\begin{array}{l}\text { Sepanjang 35 tahun Encik Foo menyewa di rumah kedai } \\
\text { tersebut, hanya dua kali sahaja bangunan rumah kedai lama itu } \\
\text { dicat dan diselenggara. Bahagian ruang dalam kedai } \\
\text { mengekalkan warna asal dan bahagian luar rumah kedai dicat } \\
\text { dengan warna baru. }\end{array}$ \\
\hline Fasad & $\begin{array}{l}\text { Tidak ada sebarang penyelenggaraan dari segi fasad dilakukan } \\
\text { oleh pemilik bangunan. Reka bentuk dan seni bina asal } \\
\text { dikekalkan demi menjaga nilai warisan yang terdapat di } \\
\text { bangunan rumah kedai lama tersebut. }\end{array}$ \\
\hline
\end{tabular}

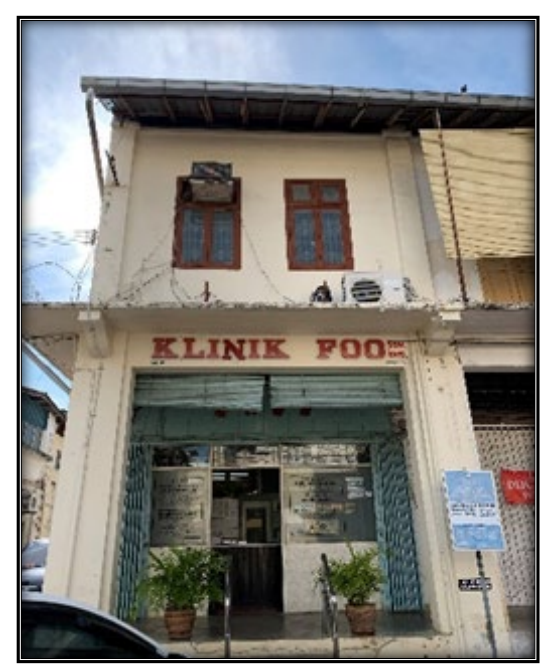

Rajah 4: Rumah Kedai Klinik Foo, 3597, Jalan Ismail, 15000 Kota Bharu, Kelantan

(Sumber: Kajian Lapangan di Bandar Kota Bharu, 2020) 
Jadual 2: Penyelengaraan Terhadap Rumah Rumah Kedai Klinik Foo, 3597, Jalan Ismail

(Sumber: Kajian Lapangan di Bandar Kota Bharu, 2020)

\begin{tabular}{|l|l|}
\hline Elemen & \multicolumn{1}{|c|}{ Huraian Bagi Setiap Elemen } \\
\hline Dinding & $\begin{array}{l}\text { Dinding Klinik Foo tidak diselenggara dengan kerap. Penjagaan } \\
\text { hanya dilakukan dengan mengecat dinding klinik sahaja. Pengkaji } \\
\text { juga tidak menjumpai sebarang kerosakan di kawasan dinding rumah } \\
\text { kedai Klinik Foo. }\end{array}$ \\
\hline Siling & $\begin{array}{l}\text { Bangunan rumah kedai Klinik Foo melakukan penyenggaraan siling } \\
\text { sekali sepanjang menyewa di bangunan rumah kedai tersebut. } \\
\text { Penjagaan yang rapi telah dilakukan oleh penyewa bangunan bagi } \\
\text { mengelakkan sebarang kerosakkan berlaku. }\end{array}$ \\
\hline Lantai & $\begin{array}{l}\text { Pemilik Kedai Klinik Foo hanya melakukan penyenggaraan terhadap } \\
\text { lantai di bangunan rumah kedai milik beliau sekali sahaja. laitu } \\
\text { dengan mengemas lantai bangunan rumah kedai dengan simen. }\end{array}$ \\
\hline Cat/Warna & $\begin{array}{l}\text { Klinik Foo masih mengekalkan warna asal bangunan rumah kedai } \\
\text { lama. Walaupun penyelenggaraan dilakukan dari segi mengecat } \\
\text { bangunan rumah kedai, warna cat tidak diubah dan dikekalkan } \\
\text { dengan warna putih. Bahagian dalam klinik dan luar klinik adalah } \\
\text { berwarna putih. }\end{array}$ \\
\hline $\begin{array}{l}\text { Fangunan rumah kedai Klinik Foo masih mengekalkan seni bina } \\
\text { fasad yang asal. Tidak ada sebarang penambahan dilakukan oleh } \\
\text { pemilik bangunan rumah kedai. Ubah suai hanya dilakukan } \\
\text { dibahagian tingkap rumah kedai. Tingkap di tingkat atas digantikan } \\
\text { dengan tingkap cermin. Akan tetapi reka bentuk masih dikekalkan. } \\
\text { Hanya jendela sahaja ditukar kepada jenis berkaca. }\end{array}$ \\
\hline
\end{tabular}

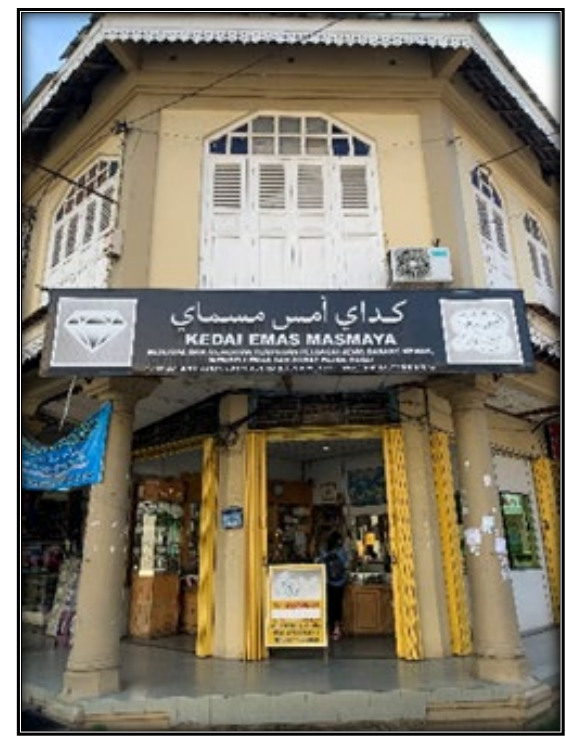

Rajah 5: Kedai Emas Masmaya, 349-D, Jalan Tengku Petra Semerah, 15000 Kota Bharu, Kelantan

(Sumber: Kajian Lapangan di Bandar Kota Bharu, 2020) 
Jadual 3: Penyelengaraan Terhadap Kedai Emas Masmaya, 349-D, Jalan Tengku Petra Semerah

(Sumber: Kajian Lapangan di Bandar Kota Bharu, 2020)

\begin{tabular}{|l|l|}
\hline Elemen & \multicolumn{1}{|c|}{ Huraian Bagi Setiap Elemen } \\
\hline Dinding & $\begin{array}{l}\text { Dinding di kedai Emas Masmaya tidak diselenggara oleh } \\
\text { penyewa kedai. Ini dapat dilihat terdapat sedikit kerosakan di } \\
\text { bahagian dinding luar kedai. }\end{array}$ \\
\hline Siling & $\begin{array}{l}\text { Menurut pekerja kedai Emas Masmaya iaitu Puan Maimunah, } \\
\text { beliau menyatakan siling di bangunan rumah kedai beliau hanya } \\
\text { ditukar sekali sahaja. Hasil daripada pemerhatian pengkaji } \\
\text { mendapati keadaan siling di bangunan rumah kedai itu sudah } \\
\text { banyak yang rosak dan perlu diselenggara dengan cepat bagi } \\
\text { mengelakkan sebarang kemalangan berlaku. }\end{array}$ \\
\hline Lantai & $\begin{array}{l}\text { Lantai di bangunan rumah kedai Emas Masmaya telah } \\
\text { diselenggara dan ditukar kepada lantai jenis mozek. }\end{array}$ \\
\hline Cat/Warna & $\begin{array}{l}\text { Bangunan sudah di cat sebanyak satu kali sepanjang 10 tahun } \\
\text { Puan Maimum bekerja disitu. Bahagian dalam rumah kedai } \\
\text { masih mengekalkan cat warna asal iaitu cat berwarna putih } \\
\text { manakala bahagian luar bangunan iaitu fasad kedai di cat } \\
\text { dengan warna coklat cair. }\end{array}$ \\
\hline Fasad & $\begin{array}{l}\text { Pemilik bangunan rumah kedai masih mengekalkan reka bentuk } \\
\text { dan seni bina asal fasad rumah kedai lama ini. Tidak ada } \\
\text { sebarang perubahan dan penambahan dilakukan }\end{array}$ \\
\hline
\end{tabular}

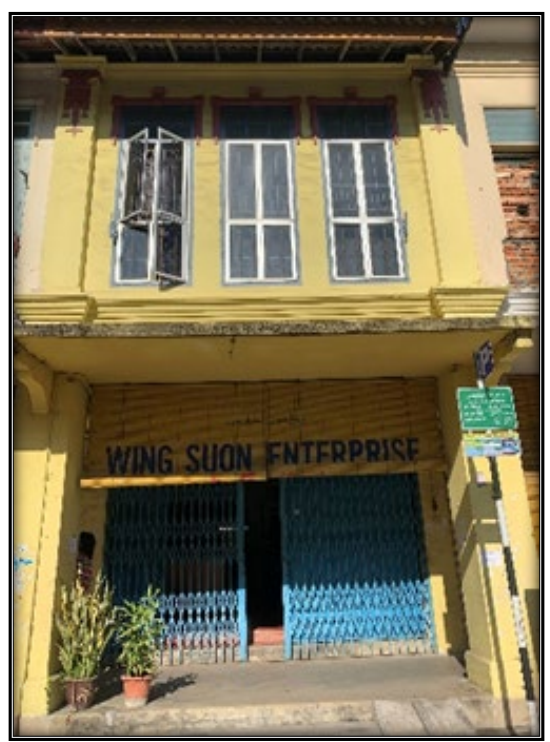

Rajah 6: Rumah Kedai Win Suon Enterprise, 183 K-M, Jalan Ismail, 15000 Kota Bharu, Kelantan

(Sumber: Kajian Lapangan di Bandar Kota Bharu,2020) 
Jadual 4: Penyelengaraan Terhadap Rumah Kedai Win Suon Enterprise, 183 K-M, Jalan Ismail

(Kajian Lapangan di Bandar Kota Bharu, 2020)

\begin{tabular}{|l|l|}
\hline Elemen & \multicolumn{1}{|c|}{ Huraian Bagi Setiap Elemen } \\
\hline Dinding & $\begin{array}{l}\text { Dinding kedai Wing Suon tidak pernah diselenggara dan } \\
\text { keadaannya masih baik. Dinding hanya dipenuhi kertas-kertas } \\
\text { yang ditampal dan tidak dibuang dengan sempurna hingga } \\
\text { meninggalkan kesan. }\end{array}$ \\
\hline Siling & $\begin{array}{l}\text { Istimewanya rumah kedai Wing Suon ini adalah siling di rumah } \\
\text { kedai ini adalah dari seni bina lama. Pemilik bangunan rumah } \\
\text { kedai ini mengekalkan reka bentuk lama. Dapat dilihat reka } \\
\text { bentuk siling lama yang beralaskan kayu dinding bahagian atas } \\
\text { rumah kedai. Hal ini secara tidak langsung pengkaji dapat } \\
\text { mengetahui reka bentuk asal siling bangunan rumah kedai } \\
\text { lama. }\end{array}$ \\
\hline Lantai & $\begin{array}{l}\text { Pemilik Kedai Wing Suon hanya melakukan penyenggaraan } \\
\text { terhadap lantai di bangunan rumah kedai milik beliau sekali } \\
\text { sahaja. laitu dengan mengemas lantai bangunan rumah kedai } \\
\text { dengan simen }\end{array}$ \\
\hline Cat/Warna & $\begin{array}{l}\text { Bangunan rumah kedai Wing Suon dicat dengan warna kuning. } \\
\text { Sedikit berbeza dengan bangunan rumah kedai lama yang } \\
\text { berada di lot tersebut. Menurut pemilik bangunan, rumah kedai } \\
\text { ini telah dicat sebanyak satu kali sepanjang beliau memiliki } \\
\text { rumah kedai tersebut. Warna cat di bahagian dalam rumah } \\
\text { kedai masih dengan warna putih dan tidak diubah kepada } \\
\text { warna lain. }\end{array}$ \\
\hline $\begin{array}{l}\text { Ubah suai hanya dilakukan dibahagian tingkap rumah kedai. } \\
\text { Akan tetapi reka bentuk masih dikekalkan. Hanya jendela } \\
\text { sahaja ditukar kepada jenis berkaca. }\end{array}$ \\
\hline Fasad
\end{tabular}

\subsection{Kesan proses penyelenggaraan ke atas bangunan rumah kedai lama}

Bangunan rumah kedai lama yang terdapat di Zon Budaya di sekitar Kota Bharu mempunyai kisahnya tersendiri. Menurut temubual bersama responden, beliau memberitahu pembinaan rumah kedai lama di sekitar Kota Bharu disebabkan pembinaan Istana Jahar yang menjadi tempat beradu Sultan. Sekiranya sesebuah kawasan mempunyai istana secara tidak langsung kawasan disekitarnya akan membangun dengan pesat. Pembinaan ini selari dengan terbinanya Bangunan Bank Kerapu dan banyak lagi bangunan warisan yang lain.

Bangunan rumah kedai lama merupakan nilai warisan bagi kebudayaan tempatan. Sebagai contoh rumah kedai Ubat Min Sin yang sudah 35 tahun beroperasi iaitu ayah Encik Foo dan kini diambil alih sendiri oleh beliau. Kerja-kerja penyelenggaraan yang telah dijalankan secara tidak langsung dapat memulihara rumah kedai lama ini daripada rosak dan dirobohkan oleh individu-individu yang tidak bertanggungjawab. Bangunan rumah kedai lama ini merupakan binaan zaman dahulu dan ini membuktikan satu teknologi yang amat unggul pada zaman tersebut yang masih dikaji sehingga kini. Kerjakerja penyelenggaraan yang dilakukan di rumah kedai lama telah membuktikan mengenai kepentingan pengekalan warisan. 


\subsection{Cadangan proses penyelenggaraan bagi rumah kedai lama}

5.3.1 Memastikan bangunan lama terpelihara dan membuat proses penyelenggaraan. Di mana penyelenggaraan yang dilakukan hendaklah lebih sistematik. Ianya dapat mengurangkan kos dan menimumkan kerugian yang mungkin berlaku semasa kerja-kerja penyelenggaraan dilakukan.

5.3.2 Kerja-kerja penyelenggaraan bangunan rumah kedai lama haruslah menggunakan tenaga pakar yang mempunyai ilmu dalam pembaikan rumah kedai lama pada zaman tersebut. Ini dapat mengekalkan hasil seni bina yang terdapat di rumah kedai lama. Selain itu, bahan-bahan yang digunakan untuk pembaikan rumah kedai lama haruslah menggunakan bahan yang sama dengan bahan asal. Sekiranya tidak dapat bahan yang sama, bolehlah menggunakan bahan yang hampir serupa supaya nilai warisan yang terdapat pada rumah kedai lama dapat dikekalkan.

5.3.3 Bagi menarik minat masyarakat untuk melawati dan mempelajari sejarah warisan rumah kedai lama, pemilik rumah kedai lama dengan bantuan kerajaan bolehlah menjadikan rumah kedai lama sebagai sebuah tempat yang menarik. Sebagai contoh menjadikan rumah kedai lama sebagai tempat makan yang bertema, sebagai tempat tarikan pelancong dan tempat golongan muda beriadah. Dengan cara ini dapat menarik lebih ramai pengunjung disamping dapat mendidik mereka berkenaan sejarah dan nilai warisan yang terdapat di rumah kedai lama.

5.3.4 Kerja-kerja penyelenggaraan haruslah dilakukan setiap bulan bagi menjaga keselamatan dan kecantikan bangunan kedai lama. Pembaharuan seperti cat baru harus dilakukan supaya bangunan rumah kedai lama kelihatan ceria.

5.3.5 Pihak kerajaan terutamanya haruslah menjadi nadi penggerak yang utama dalam membantu memberikan peruntukan kewangan khas untuk kerja-kerja pemuliharaan warisan rumah kedai lama diseluruh Malaysia. Warisan yang ada haruslah dijaga dan dilindungi untuk tatapan generasi akan datang.

5.3.6 Hasil penyelidikan juga mendapati terdapat beberapa proses penyelenggaraan yang boleh digunapakai dan boleh dilaksanakan ke atas bangunan rumah kedai lama antaranya perancangan penyelengaraan pencegahan dan perancangan penyelenggaraan pembaikan.

\section{a) Perancangan Penyelenggaraan Pencegahan}

Penyelenggaraan pencegahan adalah proses dimana penyelenggaraan yang dilaksanakan secara rutin, berkala dan berdasarkan program penyelenggaraan yang telah dirancang (planned preventive maintenance) atau penyelenggaraan jangkaan (predictive maintenance) untuk mengelakkan kemungkinan berlakunya kerosakan ke atas bangunan rumah kedai lama. Aktiviti penyelenggaraan pencegahan dilaksanakan sebelum berlakunya kerosakkan.

Pengkaji mencadangkan perancangan penyelenggaraan pencegahan dilakukan ke atas bangunan-bangunan rumah kedai lama yang terdapat di sekitar zon budaya di Kota Bharu. Penyelenggaraan pencegahan didefinisikan sebagai penjagaan bagi mengekalkan prestasi fasiliti/ alatan/ infastruktur/ bangunan pada tahap yang memuaskan melalui pemeriksaan, pengesahan dan pembetulan 
dengan sistematik sebelum berlakunya kerosakan atau kegagalan fungsi yang besar ke atas bangunan.

Penyelenggaraan pencegahan yang dilakukan ke atas bangunan rumah kedai lama boleh dilakukan oleh pemilik atau penyewa bangunan dengan membuat penjadualan penyelenggaraan pencegahan mengikut masa. la boleh dilakukan sama ada secara harian, mingguan, bulanan, tahunan dan lain-lain mengikut tahap keperluan bangunan rumah kedai lama tersebut. Penyelengaraan pencegahan boleh dipraktikan di semua bangunan rumah kedai bagi mengelakkan berlakunya kerosakan pada skala besar dan memerlukan perbelanjaan yang besar untuk membaiki.

\section{b) Penyelenggaraan Pembaikan}

Penyelenggaraan pembaikan merangkumi kerja-kerja pembaikan dan pembaharuan dengan menggantikan komponen atau eleman bangunan rumah kedai lama yang sudah rosak bagi memulihkan fungsi bangunan. Dalam konteks kejuruteraan, penyelenggaraan pembaikan merupakan penggantian bahagianbahagian komponen sebelum komponen tersebut mencapai jangka hayatnya bagi mengelakkan berlakunya kerosakan yang lebih serius.

Pengkaji telah mencadangkan untuk melakukan perancangan penyelenggaraan pembaikan ke atas bangunan rumah kedai lama yang dikesan mengalami kerosakan. Penyelenggaraan pembaikan melibatkan kerja-kerja pembaikan dan pemulihan kepada fungsi-fungsi dan keadaan asal setelah sesuatu bangunan warisan itu mengalami kerosakan atau kegagalan. Tindakan yang segara akan diambil bagi mengelakkan masalah kerosakan dan kecacatan menjadi lebih serius.

Bagi bangunan rumah kedai lama, perancangan penyelenggaraan pembaikan hendaklah dilakukan oleh pemilik bangunan rumah kedai lama. Pemilik rumah haruslah mengenal pasti terlebih dahulu kerosakan yang berlaku ke atas bangunan milik mereka. Melalui pemerhatian yang dilakukan oleh pengkaji, terdapat beberapa buah rumah kedai lama di mana siling di bangunan rumah kedai tersebut sudah rosak dan pemilik bangunan hendaklah merancang penyenggaraan pembaikan siling tersebut.

Kerja-kerja penyelenggaraan yang dilakukan haruslah mengikut skop kerja-kerja penyelenggaraan yang telah diatur berdasarkan pemeriksaan kerosakan terhadap elemen bangunan rumah kedai lama. Sekiranya berlaku kerosakan pada elemen dan komponen bangunan rumah kedai lama seperti siling, maka penyelenggaraan pembaikan akan dijalankan pada siling sahaja. Perancangan penyelenggaraan pembaikan dapat memulihara dan memelihara bangunan rumah kedai lama dalam keadaan yang baik dan memanjangkan usia bangunan. 


\subsection{Cadangan}

Pelbagai cadangan telah dirangka dalam penambahbaikan bagi mempraktikan kerja-kerja penyelenggaraan dan pemuliharaan bangunan rumah kedai lama. Antara cadangannya adalah:

\subsection{Pemantapan Polisi, Undang-undang dan Organisasi}

Akta Warisan Kebangsaan 2005 dikuatkuasa bagi menjaga dan melindungi warisan negara. Dengan adanya akta ini, pemuliharaan dan pemeliharaan bangunan warisan dapat dilaksanakan tanpa sebarang halangan. Polisi yang ada pada masa kini hendaklah dikukuhkan lagi, hal ini kerana masih terdapat bangunan warisan yang tidak diselenggara dan dijaga. Organisasi yang sedia ada seperti Jabatan Warisan Negara dan pihak berkuasa di peringkat negeri haruslah lebih peka terhadap pengurusan bangunan rumah kedai lama dengan memberi keutamaan dalam pemuliharaan, penyelenggaraan dan pemeliharaan warisan.

\subsection{Komitmen Semua Pihak}

Pihak Berkuasa Negeri, badan bukan kerajaan (NGO), pemilik, penyewa, pekerja dan masyarakat perlu terlibat secara serius. Setiap pihak haruslah peka akan isu semasa dan masalah-masalah yang sering dihadapi oleh bangunan rumah kedai lama. Pemantauan haruslah dilaksanakan dan kerja-kerja penyelenggaraan haruslah dilaksanakan dengan mengikut standard yang telah ditetapkan. Hal ini dapat menjaga dan mengekalkan seni bina dan nilai warisan yang terdapat pada bangunan rumah kedai lama.

\subsection{Kesimpulan}

Pengkaji mendapati terdapat pelbagai kerja-kerja penyelenggaraan telah dilaksanakan ke atas bangunan rumah kedai. Penyelenggaraan yang dilaksanakan secara tidak langsung dapat memulihara dan memelihara keadaan bangunan rumah kedai tersebut. Penyelenggaraan yang dilaksanakan telah mengikut standard (SOP) yang telah ditetapkan. Akan tetapi masih terdapat kelemahan dalam melaksanakan kerja-kerja penyelenggaraan pada bangunan rumah kedai lama atas sebab dan masalah yang tertentu. Kajian ini juga sememangnya dapat membantu dalam meningkatkan kefahaman di samping boleh dijadikan sebagai pemangkin ke arah penyelenggaraan bangunan rumah kedai lama yang lebih berkesan pada masa hadapan.

\section{Penghargaan}

Penyelidik mendapat sumbangan dana daripada Skim Geran Jangka Pendek dari Universiti Malaysia Kelantan (SGJP) (R/SGJP/A0200/01538A/001/2019/00585). Penyelidik ingin merakamkan ucapan terima kasih atas sokongan dan kerjasama semua pihak yang terlibat baik secara langsung ataupun tidak langsung, Kementerian Pendidikan Malaysia (KPM) dan Pusat Pengurusan Penyelidikan, Inovasi dan Pengkomersialan (RMIC) dalam menyokong projek penyelidikan ini. 


\section{Rujukan}

Akta Warisan Kebangsaan 2005, Jabatan Warisan Negara, Garis Panduan Pemuliharaan Bangunan Warisan.

Bakhir, N. M., dan Zainal, N. (Eds.). (2015). Penerokaan Teknologi Melalui Seni Dan Warisan Dalam Kearifan Tempatan (Penerbit USM). Penerbit USM.

Courtenay, B., Merriam, S., dan Baumgartner, L. (2003). Witches ways of knowing: integrative learning in joining a marginalized group. International journal of lifelong education, 22(2), 111-131.

David, GS (1992). Provinces Confronting the State? Pp 3.2-19 in China Review 1992, edited by Hsin-chi dan Maurice Brosseau (eds) Kuan. Hong Kong: CUHK Press.

Idid, S.Z.A. (1996). Pemeliharaan warisan rupa bandar Kuala Lumpur: Badan Warisan Malaysia.

Jalan, P. P. K. P. P., dan Koridor, D. (2020). Laporan Penelitian, Burra Charter di dalam Artikel 4.1.

Jamal, D. H. D., dan Ramli, Z. (2021). Pemuliharaan beberapa bangunan bersejarah di Kelantan: Tinjauan ke atas penglibatan komuniti setempat dalam suai guna semula (Conservation of several historic buildings in Kelantan: A survey on involvements of the local community in adaptive reuse). Geografia-Malaysian Journal of Society and Space, 17(2).

Orbasli, A. (2008). Architectural conservation. Oxford: Blackwell.

Wan Ismail, W.H. (2012). Sustainability of buildings in historic city of Malaysia. Asian Journal of Environment-Behaviour Studies, 3(10), 57-59. 